Revista Eletrônica Geografar, Curitiba, v. 2, Resumos do VI Seminário Interno de Pós-Graduação em Geografia, p. 44-44. Junho/2007

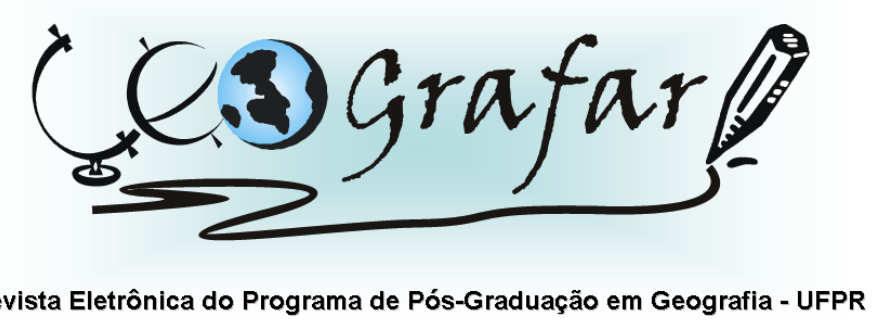

\title{
POTENCIALIDADE AO ASSOREAMENTO NA REPRESA DO PIRAQUARA I
}

\author{
LEANDRO JOSÉ RIBEIRO GUIMARÃES ${ }^{1}$
}

O assoreamento de um reservatório consiste em um problema de suma importância a ser diagnosticado. Afeta a qualidade da água e compromete seu uso para o consumo humano como, por exemplo, quando da criação de condições para a proliferação de algas. $\mathrm{O}$ tratamento da água tem exigido aumento no tempo de permanência da água nas unidades de tratamento e a aplicação de vários produtos químicos para manter os padrões exigidos para abastecimento humano, aumentando os custos, que acabam sendo repassados para a população. A deposição contínua ou gradual do material transportado pelos cursos d'água no interior de um reservatório, chamado de assoreamento, ocorre por meio da diminuição de velocidade e da turbulência das águas, que acaba por gerar sua perda de capacidade de transporte. $\mathrm{O}$ assoreamento afeta ainda a capacidade de geração de energia elétrica. Um grande número de reservatórios brasileiros encontra-se totalmente ou parcialmente assoreados, principalmente os de pequeno e médio porte. Os rios que deságuam na represa do Piraquara I constituem potenciais significativos ao processo de assoreamento, uma vez que suas bacias são contribuintes de sedimentos ao mesmo. A partir das potencialidades à erosão laminar destes contribuintes da represa do Piraquara I, por meio de levantamentos como a declividade e o uso e ocupação do solo, é possível diagnosticar qual o potencial ao processo de assoreamento existente no reservatório. Este tipo de diagnóstico pode orientar para projeções futuras relativas a mecanismos de preservação e, conseqüentemente, melhorias das condições de vida e abastecimento das populações servidas por este reservatório.

Palavras-chave:assoreamento, erosão laminar, represa do Piraquara I.

${ }^{1}$ Mestrando em Geografia - UFPR - email: leandrojrguimaraes@hotmail.com Orientador: LEONARDO JOSÉ CORDEIRO SANTOS 